Tomasz Gęsina

UNIWERSYTET ŚLĄSKI W KATOWICACH

e-mail: tomasz.gesina@gmail.com

(iD http://orcid.org/0000-0001-9351-3777

\title{
Niezwykłość gór \\ Krajobraz tatrzański w poezji Kazimiery Alberti
}

\section{Abstract \\ The uniqueness of the mountains \\ Tatra landscape in the poetry of Kazimiera Alberti}

The article deals with the subject of the Tatra landscape in Kazimiera Alberti's debut poems published in the yearbook „Wierchy” (1926) and in the volume „Avalanche revolt" (Bunt lawin) (1927). The author, referring to the earlier achievements of the Tatra literature, especially the Young Poland period, presents the most important motifs concerning the mountains in the Polish poet's work - symbolism of nature, fascination with highlander culture, embedding the action of works in Tatra space. All this adds up to a special "tatro(geo)graphy", which is an underspecified, poetic map of the Tatra Mountains and their surroundings.

Key words: Kazimiera Alberti, Tatra landscape, Tatra Mountains in Polish literature Słowa kluczowe: Kazimiera Alberti, krajobraz tatrzański, Tatry w literaturze polskiej 
Kocham Tatry. Kocham ich pustkę i milczenie, ich martwość i spokój posępny. W ich mgłach błąka się myśl moja i szuka dawnych swoich wierzeń i miłości, uczuć i sił. Po ich dolinach i przełęczach chodzi myśl moja i smuci się, że nie można być ogniem w ogniu, wichrem w wichrze, światłem w świetle; że nie można być z wami, być waszym, o duchy żywiołów! Nad potokami usiada myśl moja i smuci się, że nie można być częścią poezji świata, ale tylko dręczyć się trzeba tym, że się ją widzi i czuje, niedostępną, daleką, świętą i wzgardy pełną.

(Stara ksiq̨żka w: Przerwa-Tetmajer 1902: 205-206)

\section{Literacki fenomen Tatr ${ }^{1}$}

Geograficzne usytuowanie Polski sprawiło, że jest ona państwem odznaczającym się interesującymi walorami krajoznawczymi. Dostęp do morza, tereny nizinne i wyżynne oraz pasma górskie świadczą o jej różnorodności - nie powinien zatem dziwić fakt, że te szczególne obszary znalazły odzwierciedlenie w literaturze, która, wraz z prowadzonymi nad nią badaniami naukowymi, konstytuuje wiedzę o krajobrazie (Kubacki 1948: 65). Zapisy dotyczące niezwykłości polskiej przestrzeni geograficznej pojawiały się w twórczości wielu rodzimych pisarzy w różnych epokach. Jednym z kluczowych elementów tego krajobrazu stały się góry, wśród których wyjątkowe miejsce zajmuje najwyższe pasmo w łańcuchu Karpat - Tatry.

Michał Jagiełło, we wprowadzeniu do antologii wierszy Tatry i poeci, zauważa, że postrzeganie gór jako miejsca interesującego dokonywało się stopniowo. Dopiero dostrzeżenie ich walorów praktycznych sprawiło, że zaczęto na nie patrzeć w inny sposób. Od połowy XVIII wieku, dzięki popularyzacji hasła „powrót do natury” Jana Jakuba Rousseau i rozwojowi nauk przyrodniczych, góry stały się obiektem zainteresowań zarówno uczonych, jak i artystów. W wierszowanym utworze z roku 1564 o Tatrach wspomniał Ślązak Artur Schroeter, przebywający podówczas na dworze Olbrachta Łaskiego. Z kolei we fragmencie kroniki Macieja Stryjkowskiego, wydanej w 1582 roku, po raz pierwszy pojawia się nazwa „Tatry”, które były znane również jako „Krapak, Krępak, Karpak”. Nieco później - w XVII i XVIII wieku - najwyższe polskie góry są synonimem niebezpieczeństwa w poezji, m.in. Daniela Naborowskiego czy Zbigniewa Morsztyna. Ponadto warto zaznaczyć, że pierwszym twórcą, który

1 Ta część artykułu ma charakter wprowadzający i służy uwzględnieniu najważniejszych etapów w kształtowaniu się wizerunku Tatr w literaturze polskiej, zwłaszcza okresu Młodej Polski, który wpłynął na sposób ujęcia tego tematu przez późniejszych twórców, w tym przez Kazimierę Alberti. Bardziej dociekliwych czytelników odsyłam do dwóch najważniejszych pozycji, z których korzystałem podczas pracy nad tą częścią artykułu: Jagiełło 2007: 15-87; Kolbuszewski 1992: III-LXX.

136

Fabrica Litterarum Polono-Italica | 2019, nr 1 (1) 
w całości poświęcił utwór Tatrom, był Jakub Kazimierz Haur (Jagiełło 2007: 17-22). Nietrudno zatem zauważyć, iż początkowo to najwyższe pasmo Karpat pojawiało się w utworach polskich pisarzy epizodycznie. Stan ten trafnie podsumowuje Jacek Kolbuszewski, który wskazuje, że:

rachunek literatury tatrzańskiej przed 1832 rokiem przedstawiał się [...] raczej skromnie. W czasie gdy pełnię rozwoju przechodziły szkoła litewska i ukraińska, w obrazowaniu Tatr posługiwano się najczęściej metodami proweniencji jeszcze klasycystycznej, przejmując tylko niektóre elementy romantycznej techniki postępowania literackiego. [...] Zaważyło na fakcie znikomości literackiej roli Tatr i to, że góry te nie mieściły się jeszcze w ramach pojęcia zjawiska egzotycznego, gdy przykład Byrona kierował uwagę na Wschód, a twórczość Mickiewicza ideał egzotyki upatrywała w krajobrazie krymskim (Kolbuszewski 1971: 66-67).

Dopiero eksploracja Tatr i zainicjowanie badań naukowych przez Stanisława Staszica zapoczątkowało znaczący wzrost zainteresowań Tatrami. Szczególnym momentem okazuje się wspomniany przez Kolbuszewskiego rok 1832, kiedy Seweryn Goszczyński pisał Dziennik podróży do Tatrów. Utwór autora Zamku kaniowskiego był pierwszym wielkim dziełem poświęconym w całości fenomenowi krajobrazu tatrzańskiego. Goszczyński w dzienniku zachwycał się góralami, ich kulturą, natomiast góry postrzegał, zgodnie z ówczesną, romantyczną proweniencją, jako siedlisko fantastycznych stworzeń. W późniejszych latach Wincenty Pol podjął się skodyfikowania charakterystycznych motywów pojawiających się w poezji o Tatrach. Jako autor tatrzańskich utworów (Pieśni o ziemi naszej i Obrazów z życia i z podróży) wyodrębnił postawę człowieka charakteryzującego się zarówno indywidualnością, swobodą, jak i zrozumieniem własnej małości i marności wobec skalnych szczytów (Jagiełło 2007: 23-42).

W 1873 roku powstało Towarzystwo Tatrzańskie, co przyczyniło się m.in. do stopniowego odkrywania Tatr i Zakopanego. Pod koniec XIX wieku, zdaniem Kolbuszewskiego, rozwijała się już turystyka masowa, co z kolei zaowocowało w XX stuleciu permanentną urbanizacją Tatr i Podhala (Kolbuszewski 1992: VIII-IX). Zakopane, jako miejsce mające uzdrowiskowe walory, stało się również celem wielu twórców, którzy powracali do zdrowia w górskim klimacie. Jednym z nich był Stanisław Witkiewicz, autor Na przełęczy, synkretycznego dzieła, opisującego wędrówkę pisarza po Tatrach. Nastała moda na poznawanie tamtejszego krajobrazu górskiego (pozorna fascynacja stylem życia górali, tzw. góralomania, i przyrodą tatrzańską) oraz jego utrwalanie w literaturze. Na okres Młodej Polski przypada apogeum tematyki tatrzańskiej, kiedy to niemal każdy twórca miał w swoim dorobku co najmniej jeden utwór dotyczący Tatr. Spośród wielu nazwisk warto wymienić dwóch poetów - Kazimierza Przerwę-Tetmajera i Jana Kasprowicza - którzy burzę

137

Fabrica Litterarum Polono-Italica | 2019, nr 1 (1) 
i wiatr halny uczynili znaczącymi motywami wykorzystywanymi podczas kreowania literackiego krajobrazu tatrzańskiego. Tatry i sąsiadujące z nimi Podhale stały się w literaturze polskiej tym, czym kiedyś były Kresy Wschodnie, na co wskazywał Julian Krzyżanowski:

Gdyby zapytać, jakie strony Polski w obrębie ostatnich stu lat wiązały się szczególnie trwale z literaturą, odpowiedź brzmiałaby niewątpliwie: Tatry i Podhale. [...] Jak w czasach Słowackiego krainą najchętniej nawiedzaną przez muzę romantyczną były „Ukrainy błękitne pola”, tak w sto lat później zainteresowania literackie skupiły się wokół Podhala (Krzyżanowski 1957: 5).

Wpływ młodopolskich poetów piszących o Tatrach był znaczący - w kolejnych latach wielu twórców naśladowało styl poprzedników². Wraz z odzyskaniem przez Polskę niepodległości kończy się pewien etap w literackim ujmowaniu krajobrazu tatrzańskiego. Góry te stają się przede wszystkim ciekawym etnograficznym regionem, który fascynuje niedostępnością (Jagiełło 2007: 65). W dwudziestoleciu międzywojennym twórcy nadal podejmowali problematykę tatrzańską, jednakże w kontekście ówczesnej sytuacji literackiej w naszym kraju utraciła ona znaczącą pozycję. W utworach poetów ciągle obecny był duch minionej epoki, stąd w wielu z nich pojawiają się motywy podejmowane przez Przerwę-Tetmajera czy Kasprowicza. W dwudziestoleciu międzywojennym na uwagę zasługuje twórczość Kazimiery Alberti - poetki należącej do środowiska skupionego wokół Jana Kasprowicza i jego żony Marusi - która we wczesnym okresie twórczości nawiązuje do młodopolskich wzorców pisania o krajobrazie tatrzańskim³.

\section{Poetka i góry}

Według Edmunda Rosnera Kazimiera Alberti była „jedną z najbardziej ruchliwych i wyróżniających się pisarek okresu międzywojennego" (Rosner 1982: 104). W latach dwudziestych należała do środowiska skupionego wokół małżeństwa Kasprowiczów. Gdy w październiku 1923 roku zamieszkali oni w domu zwanym

2 J. Kolbuszewski dość krytycznie ocenia twórczość naśladowców - określa ją „silnie rozbudowanym postmłodopolskim nurtem epigońskim, zarówno w prozie, jak i w poezji, operującym przejaskrawioną symboliką i wtórnym obrazowaniem w formie artystycznej ekspresji" (Kolbuszewski 1992: LVIII-LIX).

3 Warto dodać, że najnowszą poezją tatrzańską zajmują się również współcześnie badacze, czego dowodem jest publikacja Ewy Kalus (2016).

138

Fabrica Litterarum Polono-Italica | 2019, nr 1 (1) 
Harendą, zgromadzili wokół siebie wielu znakomitych pisarzy, wśród nich np. Karola Irzykowskiego czy Kornela Makuszyńskego. Właśnie w tym środowisku przebywała młoda Alberti, która dzięki obecności innych artystów rozwijała swoją literacką wrażliwość, a twórczość autora Księgi ubogich wywarła znaczący wpływ na świadomość początkującej poetki. O tym, jak ważną rolę w jej życiu odgrywał Kasprowicz i jego Harenda, chyba najlepiej świadczy wiersz napisany tuż po jego śmierci (Alberti 1930: 57-60).

W debiutanckim tomiku Bunt lawin (Alberti 1927), wydanym przez entuzjastę Tatr Ferdynanda Hoesicka, oraz w wierszach zamieszczonych w „Wierchach” (Alberti 1926) dostrzega się opisy krajobrazu górskiego charakterystyczne dla okresu Młodej Polski. Zdaniem Edwarda Rosnera pierwszy poetycki zbiór Alberti jest lirycznym pamiętnikiem, który wzbudził zainteresowanie ówczesnych krytyków literackich, m.in. Tadeusza Łopalewskiego, Józefa Birkenmajera czy Zygmunta Wasilewskiego. Zarzucano jednak autorce egzaltację i patos w obrazowaniu Tatr. Ponadto krytyków raziła nadmierna koncentracja na własnych przeżyciach, co w ostateczności przyczyniło się do tego, że krajobraz górski stał się jedynie dopełnieniem emocji, których doznaje podmiot liryczny wierszy, a nie głównym tematem debiutanckiego tomu (Rosner 1982: 114). Gdy jednak zignoruje się mankamenty wierszy opublikowanych w zbiorze Bunt lawin i na łamach „Wierchów”, dostrzeże się kilka interesujących elementów krajobrazu tatrzańskiego, wykreowanego przez Alberti, utrzymanych w przeważającej części w młodopolskiej stylistyce.

\section{Tatro(geo)grafia}

Wiele wierszy, opublikowanych w tomiku Bunt lawin i na łamach „Wierchów”, nawiązuje do realiów topograficznych Tatr. W utworach pojawiają się nazwy szczytów górskich, przełęczy, dolin, a także Zakopane. Według Kolbuszewskiego przedstawianie tematyki tatrzańskiej w utworach literackich wiązało się z formami autentycznego jej przeżywania, wynikającego z kontaktu z krajobrazem górskim (Kolbuszewski 1992: XXV). Alberti przedstawia czytelnikowi góry widziane z własnej perspektywy, oglądane w różnych porach roku. Jednym z elementów tej przestrzeni jest Zakopane, które w dwudziestoleciu międzywojennym stało się „letnią i zimową stolicą Polski", żyjącą dzięki turystyce i rekreacji (Kolbuszewski 1992: LVIII). W poezji Alberti wspomniane Zakopane przedstawione jest również jako uzdrowi-

4 Co ciekawe, w antologiach poezji dotyczącej Tatr pojawia się tylko jeden utwór Alberti - Noc przy Morskiem - co niesłusznie zawęża motyw krajobrazu tatrzańskiego w twórczości pisarki tylko do jednego wiersza. Zob. np. Kolbuszewski 1992; Jagiełło 2007.

139

Fabrica Litterarum Polono-Italica | 2019, nr 1 (1) 
sko z wieloma sanatoriami, w których leczy się m.in. chorych na gruźlicę (Wiosna w Zakopanem):

W ukrytych sanatoriach werandują chorzy,

Śledząc ciekawie krwi plamki na chusteczek webie.

Dusze hodują kłamstwa słodki, bolesny narkotyk,

A płuca wczesną wiosną oddychają gorzej.

(Wiosna w Zakopanem w: Alberti 1927: 4)

Zapoczątkowana w XIX wieku wiara w terapeutyczne właściwości górskiego krajobrazu, zdaniem autorów Nieobecnego miasta. Przewodnik po nieznanym Zakopanem, sprawiła, że w miejscowości powstawało coraz więcej letnisk, uzdrowisk, sanatoriów czy ośrodków hydroterapii, ponieważ „można [tam - T.G.] się leczyć, odpoczywając, bo tatrzańska natura błogosławione ma własności, dobrze służy duszy i ciału" (Krupa, Mazik, Szpilka 2016: 11). Jednak sanatoria są miejscami „ukrytymi”, dostępnymi tylko dla tych, którzy zmuszeni są w nich przebywać, co kontrastuje z drugą naturą Zakopanego, ukazaną w wierszach - modnego ośrodka turystyczno-rekreacyjnego, gdzie jednym z głównych celów jest nawiązywanie relacji towarzyskich. To miasto, do którego zarówno chętnie powraca się po wyczerpującej wyprawie z Kościelisk:

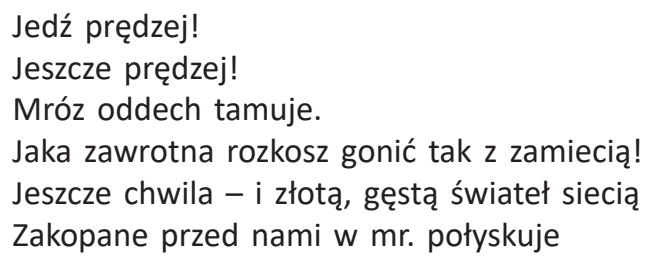

- jak i dyskretne miejsce spotkań kochanków - na Cyhrli, najwyżej położonej dzielnicy Zakopanego, bohaterowie jednego z wierszy okazują sobie miłość:

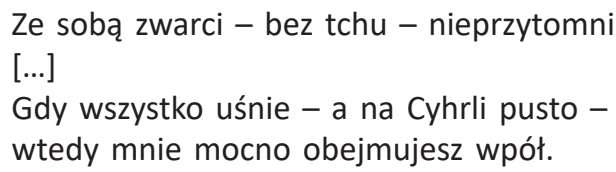

(Zjazd z Cyhrli w: Alberti 1927: 30)

Tatrzańskie szczyty bardzo często są opisywane w wierszach na tle nieba: 
Niebo jest na przedwiośniu z miękkiej, szarej irchy, Bruzdy obłoków błyszczą - niby chryzopasy Jak kratery wulkanów, dymią czarne wirchy, Świecą rozcięcia dolin; z turmaliny pasy.

(Niebo na przedwiośniu w: Alberti 1927: 3)

Podkreśla to ich monumentalność, co na dodatek uwydatniają liczne porównania. Krajobraz, oglądany ze szczytu, stanowi nie tylko emocjonalny opis przestrzeni górskiej, lecz jest również poetycką mapą uwzględniającą jej najważniejsze punkty. W utworze $Z$ Świnicy podmiot liryczny kreśli charakterystykę podziwianego miejsca, wymieniając jego najważniejsze komponenty:

U nóg Smreczyńskich dolin mir.

$[\ldots]$

Wierchcichej skrzy się kręty wąż

[...]

Sączy się HIińską metaliczny plusk,

Wolno w mgłę wsiąka Hińczowej nić.

(Z Świnicy w: Alberti 1927: 12; podkr. - T.G.)

To szczególne umiejscowienie obiektów w wierszu sprawia, iż Alberti kreuje rzeczywistość górskiego krajobrazu, w której geograficzny konkret łączy się z poetycką wyobraźnią i emocjami doświadczanymi wobec potęgi Tatr:

Bezmiar. Potęga. Otchłanne dna. Stromość.

Słońca piekąca, rozgorzała lić.

Chwila. Godzina. I smutnym - z góry - rzucamy

wiadomość:

Że dobrze żyć!!

(Z Świnicy w: Alberti 1927: 12)

Rzeczywistość, opisywana w wierszach poświęconych górom, uwzględniająca realia topograficzne, przyrodnicze oraz historyczne, miała wpływ na kształtowanie się sposobu myślenia o Tatrach jako jednego z symboli polskiej mitologii narodowej (Kolbuszewski 1992: XXV). Jednakże, jak zauważa Jagiełło, już w dwudziestoleciu międzywojennym i w poezji powojennej

wyraźnie rysuje się tendencja do rezygnowania z opisu konkretnego krajobrazu tatrzańskiego na rzecz oddawania atmosfery gór i ich oddziaływania na liryczne „ja”. Równocześnie pojawiają się utwory, w których - poza tytułem nawiązującym do Tatr - trudno doszukać się elementów obrazowania przejętych ze świata górskiego. Są to jakby wariacje na temat gór, dość daleko odchodzące

141

Fabrica Litterarum Polono-Italica | 2019, nr 1 (1) 
od właściwego przedmiotu zainteresowania. Trudno wiersze takie opatrywać etykietką „poezja tatrzańska” w tradycyjnym rozumieniu (Jagiełło 2007: 72).

W poezji Alberti opisane wcześniej tendencje łączą się - geograficzny konkret służy zarówno ukazaniu realiów górskiego krajobrazu, jak i uwydatnieniu emocji, które odczuwa podmiot liryczny jej wierszy. W wielu utworach pojawiają się również nazwy rumowisk skalnych, np. w Po deszczu: „Zmieszana z kruchym piarg i e m [podkr. - T.G.], z góry woda ścieka” (Alberti 1927: 6). Opisywanie realiów krajobrazu górskiego poprzez wykorzystywanie wyrazów związanych z geologią Tatr, podobnie jak lokalizowanie szczytów czy dolin tatrzańskich w oglądanej przez podmiot liryczny przestrzeni, po raz kolejny podkreśla związek rzeczywistości poetyckiej z tą prawdziwą, realną. Przyroda górska jest tłem, na którym rozgrywają się liczne towarzyskie spotkania. W jednym z najbardziej znanych wierszy Alberti, zatytułowanym: Noc przy Morskiem, krajobraz górski stanowi romantyczną scenerię spotkania dwojga kochanków. Zdaniem Kolbuszewskiego, ze wszystkich zakątków Tatr to właśnie Morskie Oko najbardziej utrwaliło się w kulturze polskiej (Kolbuszewski 1994: 152), urosło do rangi symbolu, odczytywanego w różnych kontekstach, również jako miłosnej scenerii, np. w twórczości Marii Pawlikowskiej-Jasnorzewskiej (Jagiełło 2007: 68) - w jednym z wierszy zakochani przebywali właśnie nad Morskim Okiem: „Nad jeziora kamiennym brzegiem razem stali / wartki wiatr rwał jej płaszczem chrzęścił w włosów złocie" (Pawlikowska-Jasnorzewska 2007: 255). W wierszu Alberti elementy przyrody są świadkami miłosnej schadzki - wiatr halny, Mnich czy Morskie Oko występują tutaj jako dopełnienie opisu namiętnego pocałunku przy ognisku („Ja Ci nie bronię - / Moich gorących, koralowych warg”; Noc przy Morskiem; Alberti 1927: 13). W tym wierszu (chyba najdobitniej w całej twórczości autorki Buntu lawin) Tatry zostały ukazane w sposób „buduarowy”, co było dość częstym motywem w literaturze popularnej okresu dwudziestolecia międzywojennego (zob. Kolbuszewski 1995: 136; Kolbuszewski 1994: 166).

Jan Majda, we wstępie do książki Młodopolskie Tatry literackie, wskazuje, że w okresie Młodej Polski pojawiło się kilka nurtów ideowych, które wytworzyły tatrzański etos społeczny. Jednym z nich była antropomorfizacja górskiego krajobrazu, która polegała na wzbogacaniu przyrody osiągnięciami kultury przy jednoczesnym zniwelowaniu opozycji człowiek - natura. „Literatura zaczęła więc przekształcać tatrzańską geosferę w teosferę i antroposferę" (Majda 1989: 9, 131-137). W poezji Alberti, jak już wcześniej wspomniano, dostrzega się wyraźne wpływy poetyki młodopolskiej. Dotyczy to również antropomorfizacji niektórych elementów tatrzańskiego krajobrazu. Tytułowy szczyt (Giewont) poetka scharakteryzowała na podobieństwo starego górala, reprezentującego wyważoną i spokojną postawę wobec świata. W wierszu tym podmiot liryczny w bezpośredni sposób zwraca się do spersonifikowanej góry: „Profil masz zimny, twardy - jak orawski gazda [...] / Takim

142

Fabrica Litterarum Polono-Italica | 2019, nr 1 (1) 
cię znam od dziecka przyjacielu stary" (Alberti 1927: 7). Zachwyt i podziw to, z jednej strony, okazywanie szacunku potędze gór, z drugiej - nieustanne próby zrozumienia tej potęgi. Nie bez powodu historię Giewontu opowiada jeden z najbardziej znamienitych przewodników tatrzańskich Wawrytko, co dopełnia paralelę pomiędzy trwaniem górskiego szczytu a życiem starego gazdy. Zakończenie wiersza - „To był najcudowniejszy - z tych, co znam - życiorys" (Alberti 1927: 7) - poświadcza, iż w swej tatrzańskiej liryce Alberti nie tylko koncentrowała się na wyrażaniu odczuwanych emocji, lecz potrafiła też ukazać majestat i surowość górskiego krajobrazu.

\section{Potęga wiatru i burzy}

We wczesnej poezji Alberti przyroda jest nie tylko statycznym elementem budzącego podziw krajobrazu górskiego. To również potęga żywiołów i zmaganie się z nimi na tatrzańskich szlakach. W okresie modernizmu szczególnie doceniono możliwości sił przyrody, ponieważ, jak zauważa Majda, umożliwiło to pisarzom wyrażanie prawd o świecie i osobistych doznań (Majda 1989: 170). Wielu poetów zwracało uwagę na dynamizm górskiego krajobrazu i wiążącą się z nim zmienność doznań, dlatego też przyroda tatrzańska stała się z czasem synonimem destrukcyjnej pracy tytanów (Jagiełło 2007: 42-43). Dla Alberti ta młodopolska stylistyka w kreacji górskich żywiołów nie była obca, stąd też w jej wczesnych utworach można doszukać się inspiracji dokonaniami poetów poprzedniej epoki.

Jedną z niszczycielskich sił przyrody, opisywanej przez twórców, jest wiatr halny. To Przerwa-Tetmajer jako pierwszy uczynił z tej siły motyw, którym posługiwali się liczni kolejni twórcy (Jagiełło 2007: 56). W wierszu Halny wiatr jego potęga została przedstawiona za pomocą licznych enumeracji, np. „Ruch, falowanie, wir, lot, pęd” (Alberti 1927: 10), które dodatkowo wzmacniają dynamizm opisywanej sytuacji lirycznej. Ruch powietrza wzbudza zarówno radość, jak i trwogę wśród oglądających, stanowi połączenie tego, co człowiek podziwia w bezmiarze gór - ich niszczycielską, a zarazem imponującą siłę. Alberti utożsamia wiatr halny z duchem młodości, zwłaszcza z emocjami, które stają się zachętą do miłosnych uniesień:

Jeszcze jeden załom, żleb i skręt I znów oddech. Uśmiechy. Zmęczenie.

Szerokie równie. Doliny. Niż.

Puste gościńce, wyręby, przestrzenie

Pijana radość. Impet. Rozpasany taniec.

I nowe siły, cudowny pęd wzwyż.

(Halny wiatr w: Alberti 1927: 10)

143

Fabrica Litterarum Polono-Italica | 2019, nr 1 (1) 
Wkomponowanie krótkiego opisu zbliżenia dwojga ludzi w charakterystykę drogi, pokonywanej przez wiatr halny od Orawicy, prezentuje namiętność jako jeden z żywiołów, któremu ulega człowiek. Dynamika ruchu powietrza łączy się z żywiołowością kochanków, dla których „zagrają wrzącej krwi hejnały - / Zahula młodość jak ten wiatr" (Alberti 1927: 11). Wiersz Alberti jest zatem afirmacją zarówno ducha młodości, jak i potęgi przyrody, uosabianej przez wiatr halny.

Znacznie trudniejszym motywem krajobrazu tatrzańskiego, opisywanym przez twórców, była górska burza. Wynikało to przede wszystkim z zastosowania różnych chwytów stylistycznych, które wyrażałyby niezwykłość zjawiska. Motyw górskiej burzy w młodopolskiej poezji został ukazany jako zjawisko groźne i fascynujące lub niszczące stary porządek świata, przyczyniając się do jego odrodzenia (Majda 1989: 175). W twórczości Alberti pojawia się przede wszystkim jako destrukcyjna siła, której doświadczają podróżujący po szlakach. W Burzy na Koszystej zjawisko zostało przedstawione na wzór spełniającej się apokalipsy, gdzie

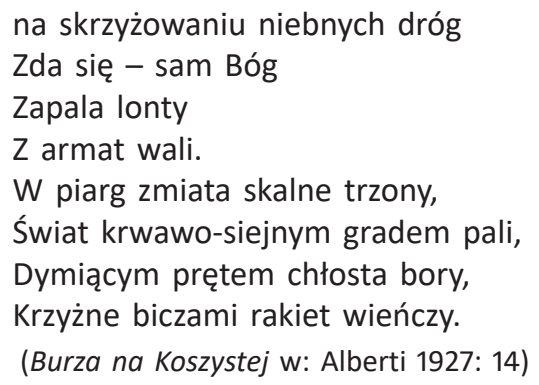

Ten destrukcyjny, zhiperbolizowany obraz prezentuje potęgę przyrody, wobec której człowiek na szlaku jest bezradny - „Do kruchych przylepieni skał / Zajadły z śmiercią prowadzimy targ" (Burza na Koszystej w: Alberti 1927: 15). W wierszu pojawiają się również nazwy poszczególnych elementów krajobrazu tatrzańskiego (Koszysta, Żółta Turnia, Dolinka Buczynowa), które odzwierciadlają ogromną skalę zjawiska, które na dodatek potęguje roztaczające się nad nimi niebo, zobrazowane za pomocą metonimii i porównania („Granatów harde cielsko jęczy / Jak struchły łach"; Burza na Koszystej w: Alberti 1927: 14). Przed niszczycielską potęgą burzy, uwydatnionej w wierszu przez wymienione wcześniej środki stylistyczne, uciekają również zwierzęta, nawet te, które w kulturze są utożsamiane z siłą i władzą - „Aż się niejedna orla głowa / W przerwiska skał z przestrachu chowa" (Burza na Koszystej w: Alberti 1927: 15). Ten nadziemny, górski pejzaż, który został wykreowany w wierszu, prezentuje fascynację Alberti młodopolskimi sposobami obrazowania potęgi przyrody, co w interesujący sposób potwierdza Burza na Koszystej.

144

Fabrica Litterarum Polono-Italica | 2019, nr 1 (1) 


\section{Zbójnik i góral}

Według Kolbuszewskiego tematyka tatrzańska w literaturze polskiej odznacza się niemal ciągłością. Podobnej konsekwencji nie można zauważyć w odniesieniu do tematyki góralskiej, która była przede wszystkim uzależniona od obecnego w danym momencie w kulturze polskiej stosunku do ludowości (Kolbuszewski 1995: 8). Idealizacja wszystkiego, co "góralskie”, rozpoczęła się w romantyzmie i nasiliła się w okresie Młodej Polski. Fascynacja strojami, tradycjami czy kuchnią górali stała się ówczesną modą, która wpłynęła również na literaturę. „Góralomanię" potęgowały legendy o awanturnikach, m.in. o Słowaku Juraju Jánošiku, który, nigdy nie będąc w Tatrach, stał się bohaterem zarówno górali, jak i zbójników. Opisany po raz pierwszy przez Goszczyńskiego, dopiero w twórczości Przerwy-Tetmajera jego postać odznaczała się indywidualizmem, sprawnością fizyczną, cechowała honorem oraz chęcią niesienia pomocy potrzebującym. Młodopolskie wyobrażenia o górskich zbójnikach zaczęto utożsamiać z góralami, których uznano za ich kontynuatorów (Jagiełło 2007: 31, 56). Ten szczególny rodzaj ludomanii był obecny również w międzywojniu, kiedy Zakopane stało się letnią i zimową stolicą Polski. W wierszu $\mathrm{Na}$ zbójnickq nutę dostrzega się ówcześnie modne zainteresowanie karpackimi zbójnikami. Utwór Alberti z topograficzną precyzją przedstawia wędrówkę awanturników, wracających od Lewoczy przez Świnicę, Liptów, przechodzących Białkę, Wag oraz Poprad, by ostatecznie udać się w kierunku Mięguszowieckich Szczytów. Ich historia permanentnego bycia $w$ drodze to główny punkt wiersza. Zbójnicy stanowią nieodłączny element krajobrazu tatrzańskiego, stali się jego komponentem niczym spersonifikowany w utworze Krywań, będący ich opiekunem:

\footnotetext{
A gdy ich siwy ociec Krywań zoczy Jak gnają od węgierskich pust Fajkę z zawiędłych wyjmie ust I stare, rysie rozpogodzi oczy.

(Na zbójnickq nutę w: Alberti 1927: 16)
}

Wiersz stanowi poetycką biografię zbójników, przemierzających górską krainę, których przygody były równie fascynujące, co niebezpieczne, ponieważ „czasem ich orla, czarna głowa / Na szubienicy pod Budzyniem błyśnie - / Kipiącym krzykiem jęknie - zwiśnie" (Alberti 1927: 17). Zakończenie wiersza jednoznacznie wskazuje, że życie tatrzańskich awanturników stało się inspiracją dla wielu entuzjastów górskiego krajobrazu, również tych największych - Witkiewicza i Chałubińskiego.

W debiutanckim tomie - obok wątku zbójeckiego - pojawia się także góralski, który uosabia postać starego Wawrytki. Ten przewodnik tatrzański, przyjaciel

145

Fabrica Litterarum Polono-Italica | 2019, nr 1 (1) 
Stefana Żeromskiego, został wykreowany w podobny sposób, co we wcześniej omówionym wierszu Giewont - to gawędziarz, który przybliża zainteresowanym historię tytułowego szczytu. W podobnym tonie jest utrzymany utwór Wizyta starego Wawrytki, opublikowany w roczniku „Wierchy” z 1926 roku. Przybycie starego, niewidomego gazdy charakteryzuje się pewną rytualnością - najpierw zapala fajkę, by następnie przejść - niczym Sabała - do opowiadania historii. Wawrytko to symbol Tatr, jego wygląd poetka zestawia z górskim krajobrazem: „ślepe oczy [...] / są niby górskie, zastygłe jeziora, / pokryte martwym bielmem siwych mgieł" (Alberti 1926: 66), natomiast głos górala przyrównuje do dźwięku poruszonego rumowiska skalnego. Opowiadane historie wprawiają słuchających w osłupienie, a postać gazdy, na pół realna, na pół legendarna, niczym Giewont góruje nad nimi - „Na ścianie cień: Wawrytki stara, sępia głowa" (Alberti 1926: 66). Alberti, wykorzystując postać słynnego przewodnika, przypomina o tych, którzy jako pierwsi zmagali się z surowością tatrzańskich szczytów - góralach - będących jednocześnie nieodłącznym elementem tamtejszego krajobrazu.

\section{W stronę refleksyjnego krajobrazu}

Debiutanckim wierszom Alberti krytycy zarzucali wiele, m.in. mieli jej za złe fakt wyeksponowania kobiecego ",ja" na tle tatrzańskiego krajobrazu. Jednakże wnikliwa lektura Buntu lawin pozwala na odnalezienie kilku interesujących wątków, z których wyłania się obraz Tatr, w większości inspirowany osiągnięciami poetów Młodej Polski. Nazwy tatrzańskich szczytów i dolin, żywioły przyrody, mieszkańcy tamtejszych okolic stanowią elementy poetyckiej topografii stworzonej przez debiutującą poetkę. Według Kolbuszewskiego to właśnie „wiersze o górach są prostą konsekwencją istnienia poezji i istnienia gór, konieczności emocjonalnego przeżywania świata, fascynacji jego wielorakością i złożonością" (Kolbuszewski 1981: 288). W późniejszych utworach Alberti, zwłaszcza z końca lat dwudziestych, przyroda nie będzie już tylko tłem, lecz stanie się przedmiotem refleksji (Rosner 1982: 114). Bunt lawin jest zatem jej pierwszą literacką próbą uchwycenia krajobrazu, w którego opisie poetka starała się zawrzeć niezwykły charakter tatrzańskiej krainy.

146

Fabrica Litterarum Polono-Italica | 2019, nr 1 (1) 


\section{Bibliografia}

AlbeRTI Kazimiera (1926): Z cyklu: Halny wiatr. „Wierchy”, R. 4.

ALBERTI Kazimiera (1927): Bunt lawin. Warszawa.

AlBerTI Kazimiera (1930): Harenda po śmierci Jana Kasprowicza. W: Eadem: Pochwała życia i śmierci. Poznań.

JAGIEŁŁO Michał (1975): Przedmowa. Do: Tatry w poezji i sztuce polskiej. Red. M. Jagiełło,

J. Woźniakowski. Kraków.

JAgIEtŁo Michał (2007): Poeci i Tatry. W: Tatry i poeci. Antologia wierszy. Wyb. i oprac. M. Jagiełło. Warszawa.

KALUS Ewa (2016): Skalne olśnienia. Współczesna poezja tatrzańsko-podhalańska. Kraków.

KolBUSZEWSKI Jacek (1971): Obraz Tatr w literaturze XIX wieku (1805-1889). Kraków.

KolBUSZEWSKI Jacek (1981): Posłowie. W: Strofy o górach. Antologia. Wyb. i oprac.

J. Kolbuszewski. Warszawa.

KolBUSZEWSKı Jacek (1992): Wstęp. W: Tatry i górale w literaturze polskiej. Antologia.

Oprac. J. Kolbuszewski. Wrocław.

KolBUSZEWSKI Jacek (1994): Przestrzenie i krajobrazy. Wrocław.

KOLBUSZEWSKı Jacek (1995): Tatry. Literacka tradycja motywu gór. Kraków.

Krupa Maciej, Mazık Piotr, SzPILKa Kuba (2016): Nieobecne miasto. Przewodnik po

Zakopanem. Wołowiec.

KRZYŻANOWSKı Julian (1957): Folklor Podhala w literaturze. „Literatura Ludowa”, nr 1.

KUBACKI Wacław (1948): Krytyk i twórca. Łódź.

MAJDA Jan (1989): Młodopolskie Tatry literackie. Kraków.

PAWLIKoWSKA-JASNORZEWSKA Maria (2007): Morskie Oko. W: Tatry i poeci. Antologia wierszy. Wyb. i oprac. M. Jagiełło. Warszawa.

PrzerWA-TetMAJer Kazimierz (1902): Wrażenia. Warszawa.

ROSNER Edmund (1982): Beskidzkie ścieżki pisarzy. Szkice literackie. Katowice.

\section{Abstract \\ L'unicità delle montagne Il paesaggio dei Tatra nella poesia di Kazimiera Alberti}

Nell'articolo viene trattato il tema del paesaggio dei monti Tatra nelle opere di debutto di Kazimiera Alberti pubblicate sull'annuario "Wierchy" (1926) e nel volume La rivolta delle valange (Bunt lawin) (1927). L'autore, rifacendosi alle ricerche già esistenti sulla letteratura dei Tatra, ed in particolare soffermandosi su quelle della Giovane Polonia, presenta i motivi più importanti riguardanti i suddetti monti nei lavori della poetessa polacca - il simbolismo della natura, il fascino della cultura montanara, lo svolgersi 
delle azioni delle opere nel panorama dei Tatra. A tutto ciò si aggiunge una speciale "tatografia", ovvero una specie di mappa poetica dei Tatra e dei suoi dintorni.

Parole chiave: Kazimiera Alberti, il paesaggio dei Tatra, i monti Tatra nella letteratura polacca 